\title{
KESULITAN SISWA DALAM MENYELESAIKAN OPERASI HITUNG ALJABAR BENTUK PECAHAN DITINJAU DARI KEMAMPUAN MATEMATIKA SISWA SMP KELAS VII SMP NEGERI 1 SALATIGA
}

\author{
Yulita Putri Aulia', Sutriyono² \\ 1,2Pendidikan Matematika, Universitas Kristen Satya Wacana, 202014080@student.uksw.edu
}

\begin{abstract}
INFO ARTIKEL
RiwayatArtikel:

Diterima: 06-03-2018

Disetujui: 22-03-2018

\section{Kata Kunci:}

Kesulitan siswa

Operasi aljabar

\section{ABSTRAK}

Abstrak: Penelitian ini bertujuan untuk mendiskripsikan kesalahan dan kesulitan siswa dalam menyelesaikan soal operasi hitung aljabar bentuk pecahan serta mengetahui factor-faktor penyebabnya ditinjau dari kemampuan matematika siswa di SMP N 1 Salatiga. Metode pengambilan subjek yaitu berdasarkan purposive sampling yang terdiri dari tiga subjek. Berdasarkan hasil dan pembahasan penelitian dapat disimpulkan bahwa 1) subjek berkemampuan rendah dan sedang melakukan tiga kesalahan konsep, prinsip, dan operasi hitung, 2) subjek berkemampuan tinggi tidak melakukan kesalahan prinsip. Kesulitan yang paling banyak dialami siswa adalah kesulitan pada konsep dan penyelesaian operasi. Faktor penyebabnya adalah pemahaman siswa yang kurang terkait aturan penyederhanaan aljabar bentuk pecahan.
\end{abstract}

Kemampuan siswa
Abstract: This research has a purpose to describe errors and difficulties of students in solving algebra arithmetic counting problems and to know the factors of student's math ability in SMP N 1 Salatiga. The data of this study were collected through purposive sampling that consisted of three subjects. The findings and resukt showed that of the research can be concluded that 1) the lowability subjects and are doing three errors of concepts, principles, and operations count, 2) highability subjects not to make a mistake principle. The most difficulties that student's faced in terms of the operation. It could be happened because the factor of students lack of understanding of the rules of algebraic simplification of fractional forms.

\section{A. LATAR BELAKANG}

Matematika merupakan satu diantara cabang ilmu yang penting. Karena pentingnya, matematika diajarkan mulai dari jenjang SD sampai dengan perguruan tinggi (minimal sebagai mata kuliah umum). Mata pelajaran matematika perlu diberikan kepada semua siswa mulai dari sekolah dasar untuk membekali siswa dengan kemampuan berpikir logis, analitis, sistematis, kritis, dan kreatif, serta kemampuan bekerjasama sehingga siswa mampu memperoleh, mengelola, dan memanfaatkan informasi untuk bertahan hidup pada keadaan yang selalu berubah, tidak pasti, dan kompetitif (Permendiknas No. 22 Tahun 2006). Lebih lanjut hal ini dijabarkan dalam tujuan pembelajaran matematika dalam kurikulum 2006 satu diantaranya adalah agar siswa mampu memahami konsepkonsep matematika dan mampu mengaplikasikannya dalam aktivitas pemecahan masalah (Depdiknas, 2006). Oleh karena itu, kegiatan pemecahan masalah oleh siswa dalam pembelajaran matematika memiliki peranan yang sangat penting.

Menurut Suherman (2003: 253), matematika adalah disiplin ilmu tentang tata cara berpikir dan mengelola logika, baik secara kuantitatif maupun berpengaruh secara kualitatif. Soedjadi (2000) mengatakan bahwa secara umum karakteristik matematika meliputi: 1) memiliki objek kajian yang abstrak; 2) mengacu pada kesepakatan; 3) berpola pikir deduktif; 4) konsisten dalam sistemnya; 5) memiliki simbol yang kosong dari arti; dan 6) memperhatikan semesta pembicara.

Menurut Indiyani dan Listiara (2006) matematika merupakan salah satu cabang pengetahuan eksak yang berhubungan dengan bilangan dan kalkulasi, sebagai bahasa simbolis untuk menunjukkan hubungan kuantitatif dan keruangan dengan penalaran yang logis, serta memudahkan dalam berpikir. Dalam mempelajari matematika siswa diharapkan mampu memahami konsepkonsep matematika untuk menyelesaikan suatu permasalahan. Tetapi kenyataannya, banyak siswa yang masih mengalami kesulitan dalam memahami konsepkonsep matematika.

Kesulitan dalam menyelesaikan soal matematika sering dialami oleh siswa, terlebih lagi karena minat siswa yang sedikit untuk belajar matematika khususnya pada materi aljabar yang dianggap sulit bagi siswa. Prosedur pembelajaran matematika lebih menekankan pada pembelajaran yang cenderung ke arah ketercapaian target materi menurut kurikulum atau menurut buku yang 
dipakai sebagai buku wajib, bukan pada pemahaman materi atau konsep yang dipelajari. Siswa cenderung menghafal konsep - konsep matematika dengan berulang - ulang menyebutkan definisi yang diberikan guru atau yang tertulis dalam buku tanpa memahami maksud dan isinya, sehingga siswa sering menghadapi kesulitan dalam menyelesaikan soal matematika yang meliputi kesulitan dalam memahami konsep, kesulitan dalam menerapkan prinsip, dan kesulitan dalam keterampilan menghitung.

Penelitian Endit (2016) menyatakan bahwa sehubungan dengan menganalisis jenis kesalahan yang dilakukan siswa dan kesulitan yang dialami siswa pada operasi aljabar bentuk pecahan terdapat 3 jenis kesalahan yaitu kesalahan konsep 25,19\%, kesalahan prinsip 43,7\%, dan kesalahan menyelesaikan operasi sebanyak 31,11\%. Dari hasil wawancara dengan subjek penelitian diketahui bahwa banyak siswa yang mengalami kesulitan pada prinsip diantaranya siswa tidak memahami sifat distributive perkalian dua aljabar dengan dua suku.

Surati (2014) menyatakan dari hasil penelitiannya menunjukan siswa mampu melakukan penjumlahan bentuk aljabar dengan benar. Namun masih ada siswa yang melakukan kesalahan dalam penjumlahan bilangan bulat, kurang memahami sifat penjumlahan bentuk aljabar dan cenderung kurang teliti. Selain itu sebenarnya siswa mampu melakukan operasi pengurangan bentuk aljabar dengan benar walaupun masih ada beberapa kekeliruan yang disebabkan oleh rendahnya kemampuan siswa dalam menjumlahkan dan mengurangkan bilangan bulat serta kurang teliti.

Berdasarkan hasil observasi pembelajaran yang telah dilakukan peneliti bersama dengan guru pada saat PPL ( Program Pengalaman Lapangan) di kelas VII A dan VII D SMP Negeri 1 Salatiga, dapat diketahui bahwa pada saat peneliti bersama guru mengajarkan materi aljabar di kelas VII D siswa mengalami kesulitan dalam mengerjakan soal terutama pada materi operasi hitung aljabar bentuk pecahan. Hal tersebut dapat terlihat dari hasil belajar siswa yang berada di bawah KKM yaitu 80. Siswa cenderung belum memahami cara penyelesaian operasi hitung aljabar bentuk pecahan pada saat mengoperasikan penyebut yang berbeda. Misalkan $\frac{2}{x+4}+\frac{3}{x-3}=\ldots$, siswa mengalami kesulitan dalam menyamakan penyebutnya. Sehingga hasil jawaban siswa yaitu $\frac{2}{x+4}+\frac{3}{x-3}=\frac{18}{x-12}$.

Berdasarkan hal tersebut maka dapat diklasifikasikan macam- macam kesulitan yang dialami siswa dalam menyelesaikan operasi hitung aljabar bentuk pecahan, diantaranya : 1) kesulitan siswa dalam memahami fakta pada operasi hitung aljabar bentuk pecahan, 2) kesulitan siswa dalam memahami konsep pada operasi hitung aljabar bentuk pecahan, 3) kesulitan siswa menerapkan prinsip pada operasi hitumh aljabar bentuk pecahan, 4) kesulitan siswa dalam menghitung operasi hitung aljabar bentuk pecahan.
Kurangnya pemahaman konsep, prinsip, dan keterampilan operasi yang dialami siswa pada materi aljabar akan menyebabkan merasa kesulitan dan membuat siswa melakukan kesalahan yang sama selama belajar. Pentingnya melakukan evaluasi untuk mengatasi kesulitan siswa dalam menyelesaikan soal khususnya dalam operasi aljabar bentuk pecahan, dengan adanya dilakukan evaluasi terhadap kesulitan siswa akan membantu seorang guru untuk mengetahui bagian manakah kesulitan yang dialami siswa. Evaluasi yang melibatkan keaktifan dan kreativitas siswa mampu meningkatkan kemampuan yang dimiliki oleh siswa.

Berdasarkan latar belakang di atas, perlu dilakukan upaya untuk mendeskripsikan kesulitan-kesulitan siswa dalam menyelesaikan soal operasi hitung aljabar bentuk pecahan. Kurangnya pemahaman konsep, prinsip, dan skill yang berupa operasi hitung pada materi aljabar dapat menyebabkan siswa melakukan kesalahan yang sama selama belajar baik materi aljabar maupun materi terkait lainnya juga menyebabkan siswa merasa kesulitan. Agar tujuan penelitian dapat tercapai dengan maksimal peneliti bermaksud untuk mendiskripsikan jenis-jenis kesalahan dan kesulitan apa sajakah yang dialami siswa dalam menyelesaikan soal operasi aljabar bentuk pecahan serta faktor-faktor penyebab yang mempengaruhinya.

\section{B. METODE PENELITIAN}

Jenis penelitian ini menggunakan pendekatan kualitatif deskriptif. Penelitian ini mendiskripsikan dan menganalisis mengenai peristiwa, pemikiran seseorang. Menurut Sugiyono (2014 :3) Penelitian kualitatif merupakan penelitian yang digunakan untuk meneliti kondisi objek yang dialami dimana peneliti sebagai instrumen terkunci, data yang pasti, serta dipandu oleh fakta-fakta yang ada di lapangan dijadikan suatu teori. Data yang dikumpul adalah data kualitatif berupa gambargambar, kata-kata secara lisan maupun tulisan, ekspresi perilaku siswa.

Subjek penelitian ini adalah 3 orang siswa yang diambil dari kelas VII D di SMP N 1 Salatiga dipilih oleh peneliti bersama dengan guru. Penelitian ini dilaksanakan pada semester ganjil tahun ajaran 2017-2018. Pengambilan data dilakukan pada bulan November sampai Desember. Subjek dipilih dengan menggunakan teknik purposive sampling. Pemilihan subjek dalam penelitian ini berdasarkan: (1) siswa yang sudah belajar materi operasi hitung aljabar bentuk pecahan; (2) siswa yang telah melaksanakan tes tertulis; (3) tiga siswa yang mempuyai kemampuan matematika tinggi, sedang dan rendah; (4) siswa yang mampu berkomunikasi dengan baik.

Instrument dalam penelitian ini adalah instrumen utama yaitu peneliti sendiri, dan instrument bantu berupa tes pemecahan masalah materi aljabar bentuk pecahan serta pedoman wawancara. Teknik pengumpulan data 
yang digunakan peneliti meliputi : 1) observasi untuk melihat dari dekat kegiatan yang dilakukan dengan cara pengamatan dan pencatatan mengenai pelaksanaan pembelajaran materi aljabar dengan guru di kelas serta mengawasi siswa saat mengerjakan soal ulangan yang diberikan guru, 2) metode tes yang nantinya diolah dan dianalisis sehingga dapat diketahui kesalahan-kesalahan yang dilakukan oleh siswa dilihat dari hasil pekerjaan siswa (subjek penelitian) saat menyelesaikan soal tes operasi hitung aljabar bentuk pecahan, 3) wawancara untuk memperkuat sumber data yang diperoleh dan untuk memperoleh informasi mengenai kesulitan apa saja yang dirasakan oleh siswa dan faktor penyebabnya, 4) dokumentasi untuk memperoleh daftar nama peserta didik kelas VIID SMP Negeri 1 Salatiga, memperoleh nilai siswa, serta mendapatkan foto saat proses pembelajaran dan kegiatan wawancara berlangsung.

Validitas instrument yang digunakan peneliti dalam penelitian ini adalah validitasi soal tes. Sebelum tes digunakan untuk penelitian, terlebih dahulu soal tes divalidasi oleh para validator. Tujuan dari validasi soal adalah untuk melihat apakah soal tes sudah sesuai dengan yang diharapkan dan benar-benar valid maka harus divalidasi oleh validator. Validasi soal dalam penelitan ini meminta masukan dari validator tentang kevalidan soal. Data validasi soal dikumpulkan dengan cara memberikan lembar validasi soal kepada validator, yaitu satu orang dosen matematika dan satu orang guru matematika.

Teknik analisis data dalam penelitian ini menggunakan 3 tahap yaitu : 1) reduksi data meliputi pengambilan hasil pekerjaan siswa kemudian mengklasifikasikan siswa menjadi 3 berdasarkan kemampuan matematika siswa yang akan dijadikan subjek penelitian dan hasilnya akan dianalisis untuk menemukan jenis-jenis kesalahan dan kesulitan yang dialami siswa serta melakukan wawancara secara mendalam dengan siswa, 2) penyajian data diorganisasikan serta dikategorikan berdasarkan indikator macam-macam kesulitan siswa dalam menyelesaikan operasi aljabar bentuk pecahan berupa deskripsi mengenai kesalahan yang dilakukan siswa, kesulitan yang dialami siswa, serata factor penyebabnya dan menyajikan hasil wawancara peneliti dengan siswa, 3) penarikan kesimpulan untuk mendeskripsikan fakta yang ada di lapangan, kemudian diambil intisarinya sehingga dapat dibuat menjadi suatu kesimpulan dari hasil penelitian.

Keabsahan data pada penelitian ini menggunakan triangulasi sumber dan teknik. triangulasi sumber penelitian ini membandingkan data hasil obserfasi, hasil pekerjaan siswa dan hasil wawancara terhadap subjek yang ditekankan pada proses yang dilakukan siswa dalam menyelesaikan operasi aljabar bentuk pecahan . Metode yang digunakan dalam penelitian ini adalah metode tes dan wawancara sehingga triangulasi metode yang dimaksud dalam penelitian ini adalah untuk mengecek keabsahan data dengan metode yang digunakan yaitu tes dan wawancara.

\section{HASIL DAN PEMBAHASAN}

Setelah melakukan penelitian, menganalisa data hasil tes siswa dan hasil wawancara, diperoleh data tentang kesulitan-kesulitan yang dialami siswa dalam menyelesaikan soal operasi hitung aljabar bentuk pecahan dan faktor-faktor penyebabnya.

Perhitungan hasil analisis dilakukan pada tiga jenis kesalahan, yaitu kesalahan konsep, prinsip, dan skill(keterampilan dalam menyelesaikan soal) karena peneliti tidak menemukan kesalahan fakta yang dilakukan siswa dalam penelitian ini. Berdasarkan hal tersebut diperoleh data sebagai berikut:

TABLE 1.

RANGKUMAN KESALAHAN HASIL PEKERJAAN SISWA

\begin{tabular}{|c|c|c|c|c|c|c|c|c|c|c|}
\hline \multirow{3}{*}{ Subjek } & \multicolumn{10}{|c|}{ No Soal } \\
\cline { 2 - 11 } & \multicolumn{2}{|c|}{1} & \multicolumn{2}{|c|}{2} & \multicolumn{2}{|c|}{3} & \multicolumn{2}{|c|}{4} & \multicolumn{2}{|c|}{5} \\
\cline { 2 - 10 } & $\mathrm{A}$ & $\mathrm{b}$ & $\mathrm{a}$ & $\mathrm{B}$ & $\mathrm{a}$ & $\mathrm{b}$ & $\mathrm{A}$ & $\mathrm{b}$ & $\mathrm{a}$ & $\mathrm{b}$ \\
\hline $\begin{array}{c}\text { Kemampuan } \\
\text { Tinggi }\end{array}$ & $\mathrm{K}$ & - & - & $\mathrm{K}$ & - & - & $\mathrm{O}$ & - & - & $\mathrm{O}$ \\
\hline $\begin{array}{c}\text { Kemampuan } \\
\text { Sedang }\end{array}$ & $\mathrm{O}$ & $\mathrm{P}$ & $\mathrm{O}$ & $\mathrm{K}$ & - & - & $\mathrm{O}$ & $\mathrm{K}$ & - & $\mathrm{O}$ \\
\hline $\begin{array}{c}\text { Kemampuan } \\
\text { Rendah }\end{array}$ & $\mathrm{K}$ & $\mathrm{K}$ & $\mathrm{O}$ & $\mathrm{P}$ & $\mathrm{O}$ & $\mathrm{O}$ & $\mathrm{K}$ & $\mathrm{K}$ & - & $\mathrm{O}$ \\
\hline
\end{tabular}

Keterarangan :
$\mathrm{K}=$ Kesalahan Konsep
$\mathrm{P}=$ Kesalahan Prinsip
$\mathrm{O}=$ Kesalahan Menyelesaikan Operasi

Rincian dari setiap kesalahan yang dilakukan siswa akan diuraikan sebagai berikut :

a. Subjek Kemampuan Tinggi (SKT)

Siswa sebagai Subjek Kemampuan Tinggi adalah Edis Oktaviani. Seperti yang terlihat pada tabel di atas, SKT melakukan kesalahan konsep pada nomor $1 \mathrm{a}$ dan $2 \mathrm{~b}$, serta kesalahan menyelesaikan operasi pada nomor $4 \mathrm{a}$, dan $5 \mathrm{~b}$.

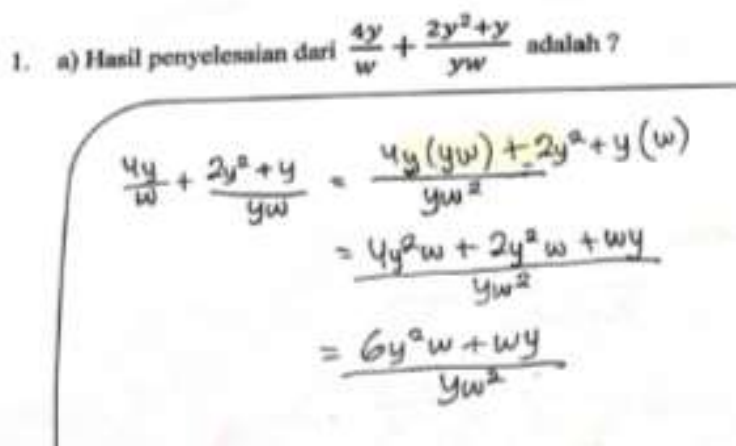

Gambar 1. Kesalahan SKT pada konsep aljabar bentuk pecahan 
2.

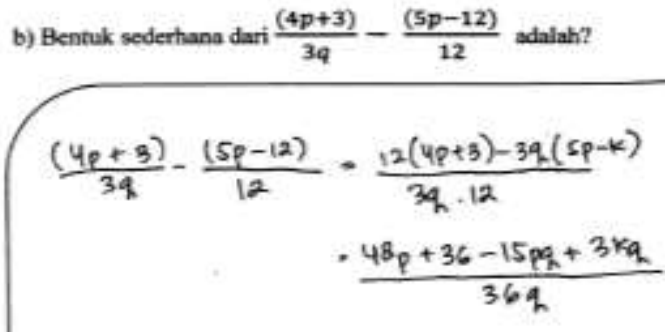

Gambar 2. Kesalahan SKT pada konsep aljabar bentuk pecahan

Pada Gambar 1 dan gambar 2 SKT melakukan kesalahan yang sama pada nomor $1 \mathrm{a}$ dan $2 \mathrm{~b}$ yaitu soal operasi penjumlahan dan pengurangan aljabar bentuk pecahan. SKT melakukan kesalahan yaitu tidak mampu dalam menyamakan penyebutnya dengan menentukan KPK, sehingga SKT tidak menyelesaikan soal dengan benar.

4. a) Bentuk sederhana dari $\frac{1}{3}+\left(\frac{4}{8 n^{2}-6}\right)$ adalah?

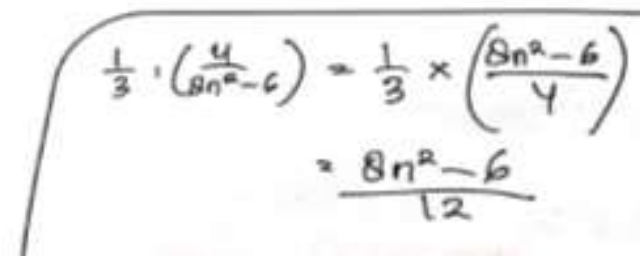

Gambar 3. Kesalahan SKT pada Penyelesaian Operasi Aljabar Bentuk Pecahan

Pada Gambar 3 SKT melakukan kesalahan pada nomor 4a yaitu soal operasi pembagian aljabar bentuk pecahan. Seperti yang terlihat pada gambar, SKT melakukan kesalahan dalam penyelesaian operasi yaitu tidak mampu menyederhanakan hasil dari operasi hitung aljabar bentuk pecahan ke bentuk yang paling sederhana.

$$
\begin{aligned}
& \text { 5. a) Hasil penyelessian dari }\left(\frac{a}{b}+\frac{c}{d}\right)^{2} \text { adalah? } \\
& \qquad \begin{aligned}
\left(\frac{a}{b}+\frac{c}{d}\right)^{2} & =\left(\frac{a}{b}+\frac{c}{d}\right)\left(\frac{a}{b}+\frac{c}{d}\right) \\
& =\frac{a^{2}+a c+a c+c^{2}}{b^{2}+6 d+b d+d^{2}} \\
& =\frac{a^{2}+2 a c+c^{2}}{b^{2}+2 b d+d^{2}}
\end{aligned}
\end{aligned}
$$

Gambar 4. Kesalahan SKT pada Penyelesaian Operasi Aljabar Bentuk Pecahan

Gambar 4 SKT melakukan kesalahan pada nomor $5 \mathrm{~b}$ yaitu soal perpangkatan aljabar bentuk pecahan. Dapat dilihat pada gambar 4 SKT melakukan kesalahan dalam penyelesaian operasi aljabar bentuk pecahan, SKT terlalu tergesa-gesa dalam mengerjakan soal serta kurang teliti dalam perhitungan, sehingga SKT tidak menyelesaikan hasil jawaban soal dengan sempurna.

Berdasarkan hasil analisis jawaban tes dan hasil wawancara dengan SKT menunjukan bahwa kesulitan konsep yang dialami siswa disebabkan karena SKT tidak mampu menyamakan penyebut pecahan dengan mencari KPK dari kedua penyebut pecahan. Kesulitan penyelesaian operasi yang dialami SKT disebabkan karena SKT terlalu tergesa-gesa dalam mengerjakan soal, sehingga kurang teliti.

b. Subjek Kemampuan Sedang (SKS)

Siswa sebagai Subjek Kemampuan Sedang adalah Dita Ayu. Seperti yang terlihat pada table di atas, SKS melakukan kesalahan konsep pada nomor $2 \mathrm{~b}$ dan $4 \mathrm{~b}$, melakukan kesalahan prinsip pada nomor 1b serta kesalahan menyelesaikan operasi pada nomor 1a, 2a, 4a, dan 5b.

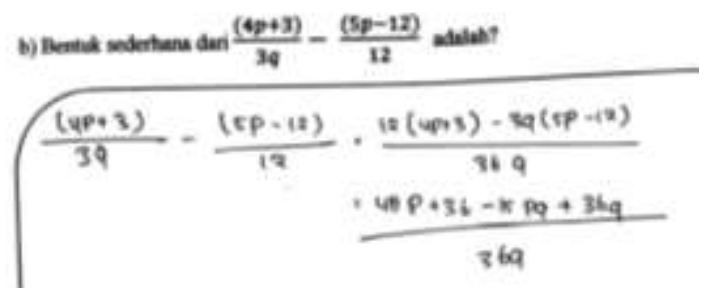

Gambar 5. Kesalahan SKS pada konsep aljabar bentuk pecahan

Gambar 5 SKS melakukan kesalahan pada nomor $2 \mathrm{~b}$ yaitu soal operasi pengurangan aljabar bentuk pecahan. Seperti yang terlihat pada gambar, SKS melakukan kesalahan dalam konsep yaitu tidak mampu menyamakan penyebut pada pecahan dengan menentukan KPK.

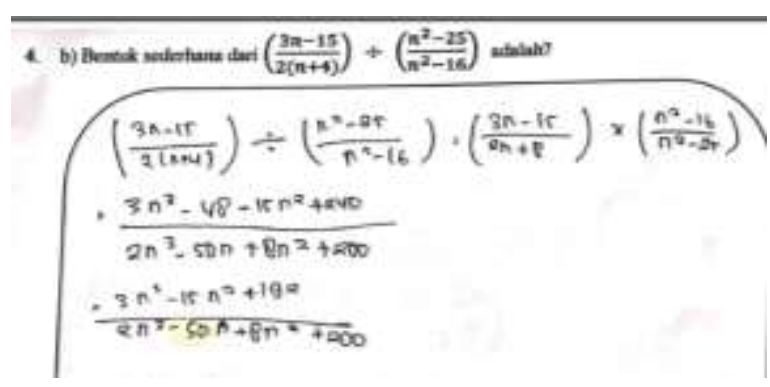

Gambar 6. Kesalahan SKS pada konsep aljabar bentuk pecahan

Gambar 6 SKS melakukan kesalahan pada nomor $4 \mathrm{~b}$ yaitu soal pembagian aljabar bentuk pecahan. Dapat dilihat pada gambar 6 SKS melakukan kesalahan dalam konsep aljabar bentuk pecahan, SKS tidak memfaktorkan, sehingga SKS tidak menyelesaikan hasil jawaban soal dengan benar. 


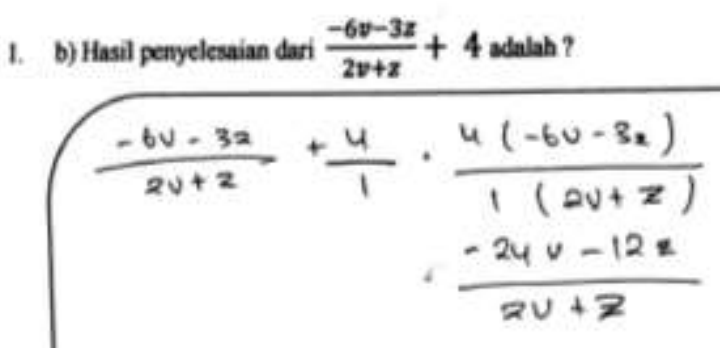

Gambar 7. Kesalahan SKS pada prinsip aljabar bentuk pecahan

Pada gambar 7 SKS melakukan kesalahan prinsip pada nomor $1 \mathrm{~b}$ yaitu soal operasi penjumlahan aljabar bentuk pecahan. Seperti yang terlihat pada gambar, SKS melakukan kesalahan dalam prinsip yaitu tidak mengalikan pembilang dan penyebut dengan bilangan yang sama pada operasi pnjumlahan aljabar bentuk pecahan.

1. a) Hasil penyelessian dari $\frac{4 y}{w}+\frac{2 y^{2}+y}{y w}$ adalah ?

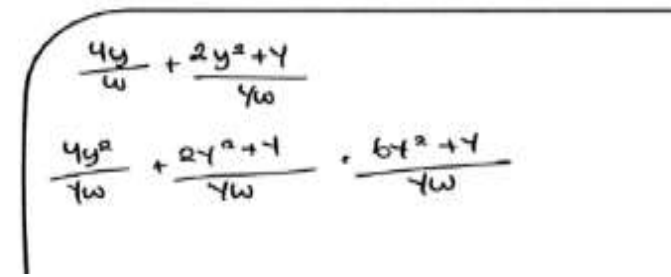

Gambar 8. Kesalahan SKS pada penyelesaian operasi aljabar bentuk pecahan

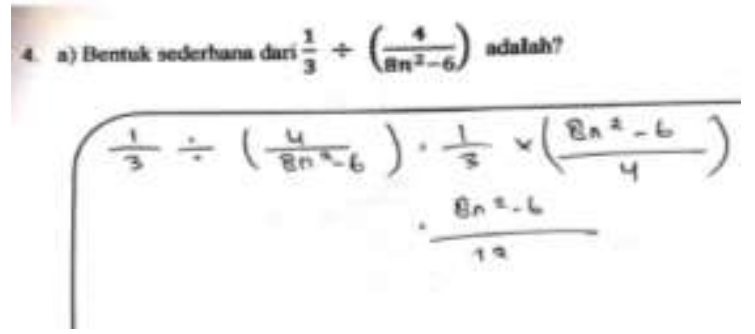

Gambar 9. Kesalahan Subjek Kemampuan Sedang pada penyelesaian operasi aljabar bentuk pecahan

Pada gambar 8 dan gambar 10 SKS melakukan kesalahan yang sama pada nomor $1 \mathrm{a}$ dan $4 \mathrm{a}$ yaitu soal operasi penjumlahan dan pembagian aljabar bentuk pecahan. Seperti yang terlihat pada gambar, SKS melakukan kesalahan dalam penyelesaian operasi yaitu tidak mampu dalam menyederhanakan hasil dari operasi hitung aljabar bentuk pecahan ke bentuk yang paling sederhana.

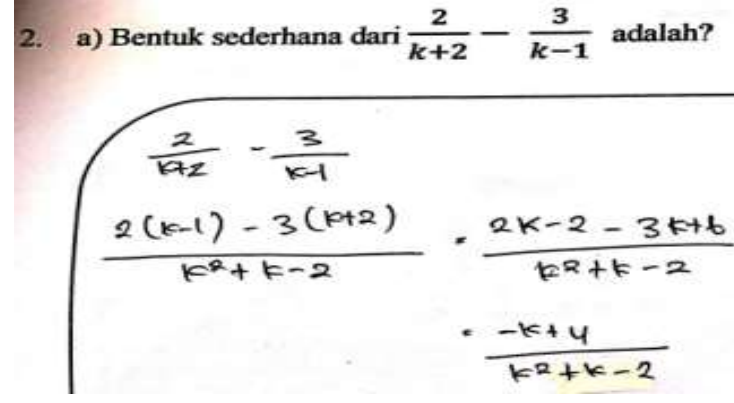

Gambar 10 Kesalahan SKS pada penyelesaian operasi aljabar bentuk pecahan

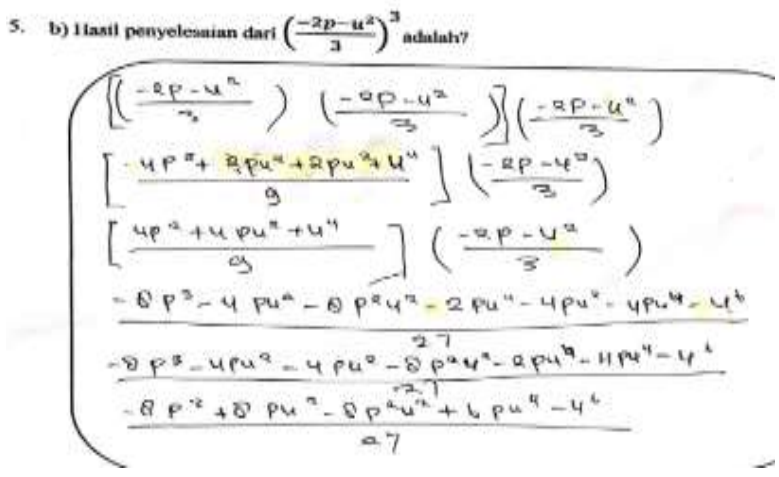

Gambar 11 Kesalahan SKS pada penyelesaian operasi aljabar bentuk pecahan

Sedangkan pada gambar 9 dan 11 SKS melakukan kesalahan yang sama pada nomor $2 a$ dan $5 b$ yaitu soal pengurangan dan perpangkatan aljabar bentuk pecahan. Dapat dilihat pada gambar 9 dan gambar 11 SKS melakukan kesalahan dalam penyelesaian operasi aljabar bentuk pecahan, SKS kurang teliti dalam perhitungan.

Berdasarkan hasil analisis jawaban tes dan hasil wawancara dengan SKS menunjukan bahwa kesulitan konsep yang dialami siswa disebabkan karena SKS tidak mahir dalam memfaktorkan. Kesulitan prinsip yang dialami SKS disebabkan karena lemahnya daya ingat SKS mengenai sifatsifat dan aturan-aturan dalam menyelesaikan soal operasi hitung aljabar bentuk pecahan. Sedangkan kesulitan penyelesaian operasi yang dialami SKS disebabkan karena kreatifitas SKS yang rendah dalam menyelesaikan soal berkaitan dengan penyederhanaan aljabar bentuk pecahan.

c. Subjek Kemampuan Rendah (SKR)

Siswa sebagai Subjek Kemampuan Rendah adalah Saumi Nurul. Seperti yang terlihat pada table di atas, SKR melakukan kesalahan konsep pada nomor 1a, 1b, 4a, dan 4b, melakukan kesalahan prinsip pada nomor $2 \mathrm{~b}$, serta kesalahan menyelesaikan operasi pada nomor $2 \mathrm{a}, 3 \mathrm{a}, 3 \mathrm{~b}$ dan $5 b$. 


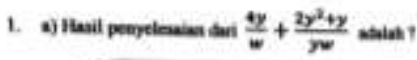

$\begin{aligned} \frac{4 y}{\omega}+\frac{2 y^{2}+y}{y \omega} & =\frac{4 y^{2}}{y \omega}+\frac{2 y^{2}+y}{y^{2} w} \\ & =\frac{6 y^{2}+y}{y^{2} w}\end{aligned}$

Gambar 12. Kesalahan SKR pada konsep aljabar bentuk pecahan

Gambar 12 SKR melakukan kesalahan konsep pada nomor 1a yaitu soal operasi penjumlahan aljabar bentuk pecahan, SKR tidak mampu menyamakan penyebut pecahan dengan menentukan KPKnya.

$$
\begin{aligned}
& \text { 1. b) Heal paycleain dari } \frac{-6 v-3 z}{2 z+z}+4 \text { adaht? } \\
& \frac{-6 v-3 z}{2 v+z}+\frac{-24 v-12 z}{8 v+4 z} \\
& \frac{-30 v-15 z}{10 v+5 z}=\frac{-3 v-3 z}{1 v+5 z}
\end{aligned}
$$

Gambar 13. Kesalahan SKR pada konsep aljabar bentuk pecahan

Gambar 13 subjek 3 melakukan 2 kesalahan konsep dalam menyelesaikan soal nomor $1 \mathrm{~b}$ yaitu SKR tidak mampu menyamakan penyebut dengan menentukan KPK serta tidak memahami konsep penjumlahan aljabar bentuk pecahan.

$$
\begin{aligned}
& \text { 4. a) Bentut nederhana dario } \frac{1}{3}+\left(\frac{4}{\operatorname{an}^{2}-2}\right) \text { ndatah? }
\end{aligned}
$$

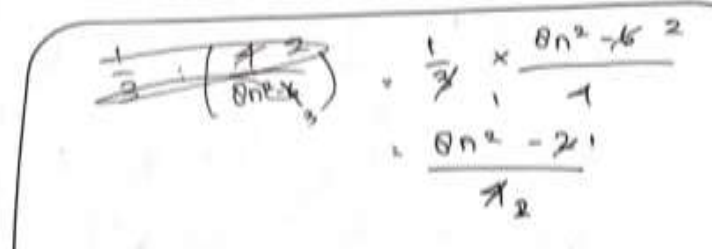

Gambar 14. Kesalahan SKR pada konsep aljabar bentuk pecahan

Pada gambar 14 SKR melakukan kesalahan konsep aljabar bentuk pecahan pada nomor $4 \mathrm{a}$, SKR salah menafsirkan konsep pencoretan dalam menyederhanakan pecahan aljabar.

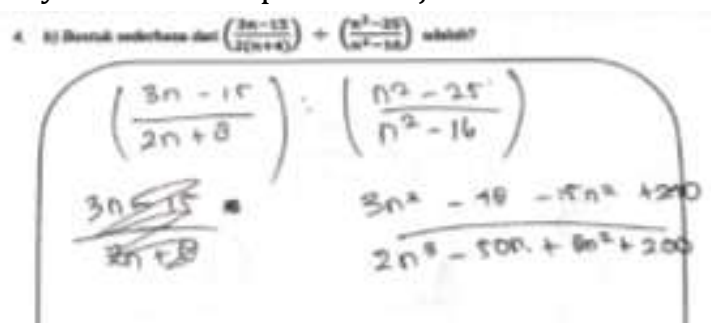

Gambar 15. Kesalahan SKR pada konsep aljabar bentuk pecahan
Gambar 15 menunjukan SKR melakukan kesalahan pada soal $4 \mathrm{~b}$ yaitu pembagian aljabar bentuk pecahan. Seperti yang terlihat pada gambar, SKR tidak memfaktorkan sehingga SKR tidak menyelesaikan soal dengan benar.

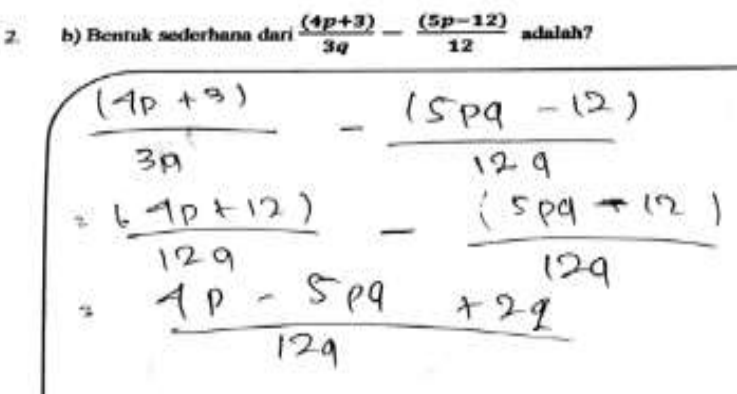

Gambar 16 Kesalahan SKR pada prinsip aljabar bentuk pecahan

Pada gambar 16 SKR melakukan kesalahan prinsip aljabar bentuk pecahan yaitu pada nomor $2 \mathrm{~b}$ soal operasi pengurangan aljabar bentuk pecahan, SKR tidak mengalikan pembilang dan penyebut dengan bilangan yang sama.

2. a) Bentuk sederhana dari $\frac{2}{k+2}-\frac{3}{k-1}$ adalah?

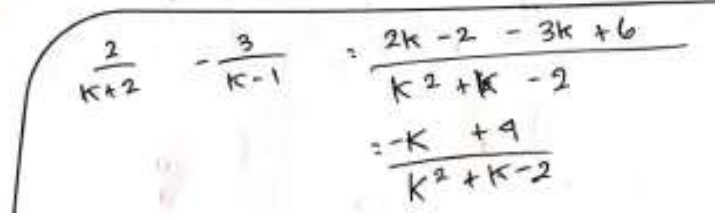

Gambar 17. Kesalahan SKR pada penyelesaian operasi aljabar bentuk pecahan

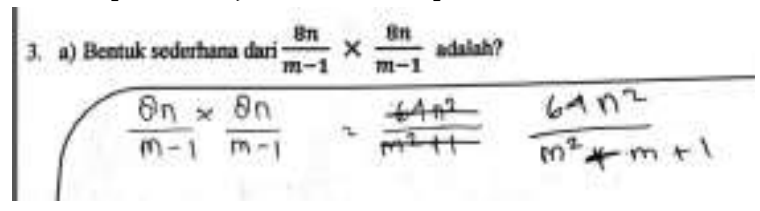

Gambar 18. Kesalahan SKR pada penyelesaian operasi aljabar bentuk pecahan

3 b) Bernak moderhara dari $\frac{(2 a-1)}{3} \times \frac{(3 a)}{19}$ adalalh

$$
\frac{(2 a-1)}{3 a} \times \frac{(8 a)}{19}=\frac{\left(2 a^{2}-1\right)}{19}
$$

Gambar 19. Kesalahan SKR pada penyelesaian operasi aljabar bentuk pecahan

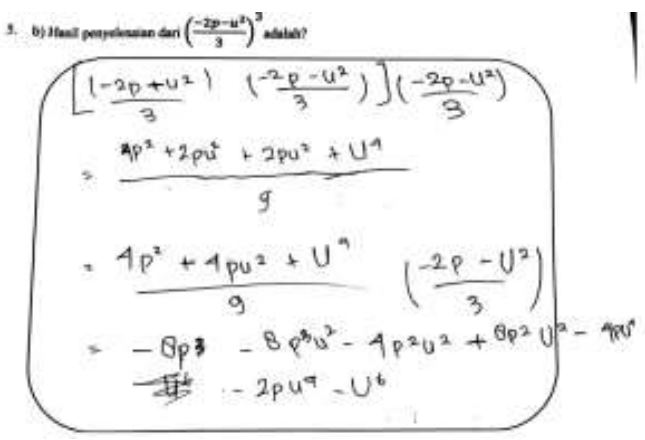

Gambar 20. Kesalahan SKR pada penyelesaian operasi aljabar bentuk pecahan 
Dapat dilihat pada gambar 17 sampai dengan gambar 20, bahwa SKR melakukan kesalahan dalam penyelesaian operasi aljabar bentuk pecahan, kesalahan yang dilakukan SKR sama yaitu SKR kurang teliti dalam perhitungan sehingga tidak dapat menyelesaikan soal dengan benar.

Berdasarkan hasil analisis jawaban tes dan hasil wawancara dengan SKR menunjukan bahwa kesulitan konsep yang dialami siswa disebabkan karena kurangnya pemahaman SKR menyelesaikan soal operasi aljabar bentuk pecahan. Kesulitan prinsip yang dialami SKR disebabkan oleh kurangnya SKR dalam melatih diri untuk mengerjakan soal-soal operasi aljabar bentuk pecahan. Sedangkan kesulitan penyelesaian operasi yang dialami SKR disebabkan karena lemahnya keterampilan hitung SKR dalam menyelesaikan soal operasi hitung aljabar bentuk pecahan serta terlalu tergesa-gesa dalam mengerjakan soal, sehingga kurang teliti.

\section{SIMPULAN DAN SARAN}

Berdasarkan hasil penelitian dapat disimpulkan:

1. Berdasarkan temuan penelitian yang dikembangkan dari tiga jenis kesalahan yang dilakukan oleh siswa SMP Negeri 1 Salatiga, dapat diketahui kesalahan-kesalahan yang dialami siswa dalam menyelesaikan operasi hitung aljabar bentuk pecahan. Adapun 3 jenis kesalahan tersebut adalah kesalahan konsep, kesalahan prinsip, dan kesalahan penyelesaian operasi. Kesalahan konsep yang dilakukan siswa yaitu a) tidak mampu menyamakan penyebut pada aljabar bentuk pecahan dengan menentukan KPK yang dilakukan oleh SKT, SKS, dan SKR, b) tidak memahami konsep penjumlahan aljabar bentuk pecahan yang dilakukan oleh SKR, c) tidak memfaktorkan yang dilakukan oleh SKS dan SKR, d) salah menafsirkan konsep pencoretan dalam menyederhanakan yang dilakukan oleh SKR.

Kesalahan prinsip yang dilakukan siswa yaitu tidak mengalikan pembilang dan penyebut dengan bilangan yang sama yang dilakukan oleh SKS dan SKR. Sedangkan kesalahan penyelesaian operasi yang dilakukan siswa yaitu : a) tidak mampu dalam menyederhanakan hasil dari operasi hitung aljabar bentuk pecahan ke bentuk yang sederhana yang dilakukan oleh SKT dan SKS, b) siswa tergesa-gesa, atau siswa kurang teliti dalam perhitungan yang dilakukan oleh SKT, SKS, dan sebagian besar dilakukan SKR.

2. Berdasarkan hasil wawancara dengan subjek penelitian diketahui bahwa banyak siswa mengalami kesulitan pada konsep. Faktor penyebab kesulitan yang dialami siswa meliputi:

a. Lemahnya daya ingat siswa mengenai sifatsifat dan aturan-aturan dalam menyelesaikan soal operasi hitung aljabar bentuk pecahan.

b. Siswa kurang mahir dalam memfaktorkan.

c. Siswa tidak dapat mengaitkan materi pada soal dengan materi yang telah diperoleh sebelumnya.

d. Pemahaman siswa yang kurang terkait aturan penyederhanaan aljabar bentuk pecahan termasuk konsep pencoretan.

e. Siswa kurang melatih dirinya dalam mengerjakan soal-soal penyelesaian operasi aljabar bentuk pecahan.

f. Siswa kurang teliti dalam melakukan operasi penjumlahan, pengurangan, perkalian, pembagian, serta perpangkatan pada aljabar bentuk pecahan.

g. Kreatifitas siswa yang rendah dalam melakukan operasi hitung aljabar bentuk pecahan.

Adapun saran yang dapat peneliti berikan bagi peneliti lain :

1. Peneliti lain yang akan melakukan penelitian sejenis disarankan melakukan ujicoba terlebih dahulu kepada siswa lain melalui guru, tujuannya agar dapat membandingkan hasil siswa bersama peneliti dengan hasil siswa bersama dengan guru. Sehingga sebelum menyusun soal tes peneliti mengetahui tingkat kesulitan soal.

2. Peneliti berikutnya yang berminat melakukan penelitian sejenis, supaya mencoba menggunakan indikator kesalahan konsep, prinsip, dan penyelesaian operasi alternatif lain yang diduga akan muncul pada penelitian lainnya.

\section{UCAPAN TERIMA KASIH}

Peneliti mengucapkan terima kasih:

1. Kepada Allah dengan segala rahmat dan karunia-Nya, selalu mengarahkan langkah peneliti dalam menyelesaikan skripsi ini.

2. Kepada Prof. Sutriyono selaku Pembimbing yang senantiasa memberikan bimbingan, nasehat, dan motivasi kepada penulis sehingga penelitian ini selesai dengan baik.

3. Kedua Orang Tua, Adik-Adik, serta keluarga besar tercinta yang senantiasa memberi dukungan kepada peneliti, perhatian, semangat, serta doa umi abi terkasih dan semuanya yang tidak henti-hentinya mengalir untuk kelancaran dan kesuksesan peneliti dalam menyelesaikan skripsi ini.

4. Kepada mas Aziz Rosidi tersayang yang selalu memberikan semangat, dukungan, perhatian kepada peniliti. Kemudian terimakasih banyak kepada 
sahabat-sahabat, Laras, Annida, teman-teman ppg dan semuanya yang telah banyak membantu menyemangati peneliti.

5. Serta masih banyak lagi piak-pihak yang sangat berpengaruh dalam proses penyelesaian skripsi yang tidak bisa peneliti sebutkan satu persatu.

\section{DAFTAR RUJUKAN}

[1] Abdurrahman, Mulyono. (2012). Anak Berkesulitan Belajar Teori, Diagnosis, dan Remidiasinya. Jakarta: Rineka Cipta.

[2] Depdiknas. 2006. Permendiknas No 22 Tahun 2006. Tentang Standar Isi. Jakarta: Depdiknas.

[3] Endit Donistyara Januarvi. 2016. "Kesulitan Siswa Dalam Menyelesaikan Operasi Hitung Aljabar Bentuk pecahan." Jurnal Pendidikan Matematika UMS.

[4] Indiyani, Novita Eka, dan Anita Listiara. 2006. "Efektivitas Metode Pembelajaran Gotong Royong(Cooperative Learning) untuk Menurunkan Kecemasan Siswa dalam Menghadapi PelajaranMatematika." jurnal Psikologi Universitas Diponegoro, Vol. 3, No. 1. Diakses pada 24 Desember 2018(http://ejournal.undip.ac.id/index.php/psikologi Larticle/view/688).

[5] Irfan, Muhammad dan Sugiman. (2014). Analisis Kesulitan Matematika Siswa SMA/MA dalam Menyelesaikan soal Setara UN di Kabupaten Maluku Tengah. Jurnal Riset Matematika, Vol 1, N0. 1, h. 22-34.

[6] Nurianti, Evi, Halini, dan Romal. 2015. "Analisis Kesalahan Siswa dalam Menyelesaikan Soal Matematika Materi Pecahan Bentuk Aljabar di Kelas VIII SMP." Jurnal Pendidikan dan Pembelajaran, Vol. 4, No. 9. Diakses pada 02 Januari 2018.

(http://jurnal.untan.ac.id/index.php/jpdpb/article/vi ew/11206).

[7] Soedjadi. 2000. Kiat Pendidikan Matematika di Indonesia. Bandung: Dirjen Dikti Depdiknas.

[8] Sugiyono. 2014. Metode Penelitian Kuantitatif, Kualitatif, dan Kombinasi (Mixed Methods). Bandung : Alfabeta.

[9] Suherman, Erman. 2003. Strategi Pembelajaran Matematika Kontemporer. Bandung: IMSTEP UPI.

[10] Surati. 2014. "Penerapan Pendekatan Realistic Mathematic Education untuk Meningkatkan Hasil BelajarSiswa MTsN Model Palu Timur pada Materi Penjumlahan dan Pengurangan Bentuk Aljabar."jurnal Elektronik Pendidikan Matematika Tadulako, Vol. 1, No. 2. Diakses pada 31 Desember 2018. (http://id.portalgaruda.org/?ref=browse\&mod=viewa rticle\&article=276787).

[11] Wiyartimi, dkk. 2010. "Diagnosis Kesulitan Belajar Siswa pada Materi trigonometri Rumus-Rumus Segitiga." JMAP 9(2): 89-99.

\section{PROFIL PENULIS UTAMA}

Penulis bernama lengkap "Yulita Putri Aulia".Lahir di Dusun Rekesan Desa Sugihan Kecamatan Tengaran Kabupaten Semarang Provinsi Jawa Tengah pada tanggal 19 Juli 1996 dari pasangan Mustaqim dan Widaryanti. Penulis adalah anak pertama dari 6 bersaudara. Pendidikan sekolah dasar dimulai dari SDN Sugihan 01 Kecamatan Tengaran pada tahun 2001 - 2006. Setelah itu melanjutkan pendidikan sekolah menengah ke SMPN 3 Tengaran pada tahun 2006 - 2009 dan terakhir di SMA Budi Utomo Jombang pada tahun 2009 - 2013. Kemudian penulis melanjutkan studi keperguruan tinggi di Program Studi Pendidikan Matematika FKIP UKSW Salatiga pada tahun 2014. Kritik, saran, maupun hal-hal yang berkaitan dengan kelanjutan atau pengembangan dari hasil penelitian ini bisa dikirim ke email penulis di : 202014080@student.uksw.edu 